\title{
Seattle in the 1960s: Music, Identity, and the Struggle for Civil Rights ${ }^{1}$
}

Rylan Kafara, University of Alberta

\begin{abstract}
During the 1960s, the American civil rights movement fundamentally altered the identity of Seattle's black community. During the proceeding decades, its process of identity formation hinged on a shared appreciation and understanding of Rhythm and Blues music. Artists like Ray Charles and Jimi Hendrix benefited from this rich musical tradition. However, the intensification of racial discord politicized the African-American community. Black music became infused with overt political melodies. While remaining a key factor in shaping black identity, it also served to mobilize the broader community against racial inequality. This article explores the role of music in the construction of black identity, a process that indelibly altered the Emerald City. By drawing upon a diverse range of contemporary sources, as well as more recent literature written on thePacific Northwest, this article highlights the ways in which a specific community relates

to, and is shaped by, one of its own cultural constructs. Ultimately, the article examines 1960s Seattle as a case
\end{abstract}

\footnotetext{
$l$ The author would like to dedicate this essay to the memory of his father. 
study of the transition within black identity that occurred all across America.

\section{Introduction}

Numerous alterations to America's cultural and political landscape during the 1960s resulted in a |77 demonstrably different country in comparison to the 1950s. This article examines one of those myriad alterations, specifically the formation of African-American identity in Seattle. Until the late-fifties, the cultural identity of Seattle's African-American community pivoted on a shared appreciation and understanding of jazz music and rhythm and blues. However, by the turn of the decade, Seattle's Caucasian music industry co-opted and marketed this black cultural artefact to mainstream American society. $R \& B$ music no longer represented the unique cultural expression of Seattle's black community. Nonetheless, during the sixties music was still to play a considerable role in the process of identity formation for Seattle's black community.

Simultaneously, the American civil rights movement was gaining momentum, reshaping African-American identity on a national scale. This article observes the intersection of music and the civil rights movement, and their roles in shaping the identity of Seattle's African American community in the sixties. The examination of these issues in tandem provides insight into the transition of the black community's process of identity formation and allows us to better observe the growth of a black civil and 
political consciousness. My intention in this article is to reveal the "in-betweens" which fuse together these two discourses. I do this by drawing on various sources, rom contemporary Seattle newspapers to works on America in the sixties, biographies on African American musicians, and literature regarding Seattle's racial tensions. Ultimately, the aim is to further debate on theconnection between politics and style, music and identity, links that remain pertinent today, as evidenced by the Seattle band Pearl Jam.

On 6 November 2000, Pearl Jam was finishing the last show of their world tour in support of their recent album Binaural. Playing in front of a hometown crowd in Seattle, front man Eddie Vedder took advantage of a break in between songs to voice a point of contention. Vedder expressed frustration over problems that arose in dealing with the municipal government in staging the concert in the Emerald City. The issue was over security and stemmed from the fact that the city asked that Pearl Jam hire two hundred and seventy security guards for the show at a cost of 25,000 dollars. This was much higher than the usual cost of 6,000 dollars for security in other cities. ${ }^{2} \mathrm{~A}$ major problem for Vedder was that all the gate-takings were to go to charity and due to extra security 19,000 dollars would no longer be going to support charity groups in need. Many of these intended beneficiary charity groups were in Seattle. Obviously frustrated by the turn of events in the band`s home town, Vedder angrily asked the crowd when

\footnotetext{
2 Pearl Jam, Live in Seattle, (Seattle, Washington, 6 November 2000). 
they thought music would finally get a higher level of respect in Seattle. ${ }^{3}$

At first glance it seems strange for Vedder to make such a remark in Seattle, a city known for a vibrant and diverse music scene. Underneath that superficial image, however, lies a cultural and ideological animosity that has existed for decades. Indeed, the "visibility of Seattle's music community," as Kim Neely points out "seemed to rise and fall in proportion with the level of tolerance displayed by local law enforcement." 4 After the Vedder's comments concerning the position of music in Seattle's cultural scene, the musician proceeded to advocate for the youth in Seattle to have a space in the city to express themselves. ${ }^{5}$ Since the municipal government had passed the Teen Dance Ordinance of 1985, venues and promoters found that holding all-age shows was virtually impossible due to the city's overbearing security and insurance demands. ${ }^{6}$ After Vedder finished talking to the crowd, Pearl Jam broke into a cover of the Who's "The Kids are Alright," as a message to Seattle's municipal government that not everyone agreed with such restricting policies.

\section{Music in Seattle's Central District}

That there were tensions between opposing sides within Seattle was not something unique to the end of the

${ }^{3}$ Ibid.

${ }^{4}$ Kim Neely. Five Against One: The Pearl Jam Story (New York: Penguin Books, 1998), 7.

${ }^{5}$ Live in Seattle.

6 Neely, 7-8. 
twentieth century. In the 1960s, a different set of tensions ultimately led to a clash that pitted reactionary Seattleites against minority groups comprised mainly of African Americans residing in the downtown Central District. The clash was over civil rights with many wishing to leave the Central District for other parts of the city. The dominant issues included the existence of an employment bias against minorities and the segregation of Seattle's schools .7 At the same time, the company Dolton Records began to market and brand to a national and international audience a particular Pacific Northwest sound. One of the specific aspects of the Dolton sound was that it was produced by musicians that were predominately white but drew heavily from black influences. This was due to a rich and vibrant black music scene in Seattle that dated back five decades.

This scene grew out of the geographic isolation of the city as well as the separateness its black community. Music served as an outlet and escape for Seattle's black population. For many living in the Central District, music was also an integral part of their identity. Suddenly that identity was being usurped and co-opted by marketable white musicians at the same time as the war for equal rights was being fought. By the end of the 1960s the fight for civil rights changed the sense of identity of the Seattle black community. The Central District then became markedly more political. Although music continued to play a role in shaping black identity, it no longer held the same

\footnotetext{
${ }^{7}$ Quintard Taylor, "The Civil Rights Movement in the American West: Black Protest in Seattle, 1960-1970," The Journal of Negro History, Vol. 80. No. 1. (Winter 1995), 1-3.
} 
position it had before the 1960s. This was made all too evident when arguably the world's most popular musician returned to his hometown of Seattle. His name was Jimi Hendrix and when he arrived home in early 1968 he found a city strikingly different from the one he had left.

Various members of Hendrix's family had been in Seattle since the 1910s. At the time, the beginnings of a music community already existed. ${ }^{8}$ The 1909 World's Fair was held in Seattle and music was one of its main attractions. A Hawaiian music craze that swept across America soon after had its roots in the Seattle fair, due to many proficient Hawaiian musicians who played there. ${ }^{9}$ Two decades earlier the Klondike Gold Rush had boosted the Seattle economy and so Orpheum and Pantages Vaudeville Theatres, important American entertainment companies, used Seattle as their base of operations. ${ }^{10} \mathrm{An}$ exciting nightlife developed, especially an early jazz scene that sprung up in the Central District, centred mainly around Jackson Street and Twelfth Avenue. ${ }^{11}$

By the 1920s, Seattle's black population numbered approximately three thousand and the jazz scene continued to thrive as more jazz clubs opened. ${ }^{12}$ The Alhambra, later

\footnotetext{
8 Patrick MacDonald and Paul De Barros.,"Seattle's Fun and Noise: From W.C. Handy to Jimi Hendrix to Robert Cray, the Emerald City has had a Rich History of Black Music," The Seattle Times, Sunday 1 February 1998. Hendrix's grandparents had been travelling vaudeville performers that had settled in the city.

9 Peter Blecha, Music in Washington: Seattle and Beyond (USA: Arcadia

Publishing, 2007), 11

10 Ibid.

11 Macdonald and Barros, 1.

12 Quintard Taylor.," Blacks and Asians in a White City: Japanese Americans and African Americans in Seattle, 1890-1940," The Western History Quarterly, Vol. 22, No., 4 (November 1991), 407.
} 
called the black and Tan, was opened by Russell "Noodles" Smith on Twelfth and Jackson. Nearby, on Twelfth and Main, the Entertainers' Club played host to jazz notables like pianist Jelly Roll Morton. ${ }^{13}$ Not only did the black community have its own entertainment district. It also had its restaurants, shops, and newspapers. ${ }^{14}$ While the black music scene was thriving, the community's economic prospects were not. Quintard Taylor argues that blacks were kept on the fringe of Seattle`s economic interests."15 Employment discrimination and educational limitations were a hindrance on the black community's efforts for better economic prospects. Revealingly, the 1930 American census shows a very small number of blacks in professions like law and medicine, while a large proportion was musicians. ${ }^{16}$ Considering that one did not need a formal education or a successful career to play music it thereby became a way to overcome the overt racism directed towards the black community.

Throughout the 1930s, the population of blacks stayed roughly the same. With the onset of the Second World War, however, thousands of blacks made their way to Seattle because the wartime increase in production created the need for a larger workforce.$^{17}$ For example, at

13 MacDonald and Barros, 1.

14 Charles R. Cross, Room Full of Mirrors: A Biography of Jimi Hendrix (New York: Hyperion Books, 2005), 13.

15 Ibid., 414.

16 Taylor, "Blacks and Asians," 415. Compared to forty-two musicians or teachers of music, there were only two lawyers, two physicians/surgeons, four trained nurses, and one school teacher. Statistics includes males and females. For an Asian workforce population twice the size, there were only eleven musicians/teachers of music.

17 Ibid., 407. 
the height of production in 1944, the Boeing Airplane Company employed 50,000 workers. In September of 1939, the company had only employed 4,000.18 By 1945, blacks were the largest minority in Seattle with the pre-war population quadrupling due to migration into the community. Seattle's African-American population rose to 15, 666 from 3,789 between 1940 and 1950, an increase of 413 percent. ${ }^{19}$ Such a substantial migration of people brought with them considerable new talent and innovations to jazz, gospel, and blues. ${ }^{20}$

Many who arrived in Seattle were from the South, another section of the same influx of blacks that had moved into Harlem and the South Side of Chicago. These newcomers had an impact on what being 'black' meant to the youth of the city. ${ }^{21}$ Buddy Catlett, a James A. Garfield High School student and saxophone player, thought the migrants "brought a welcome splash of color."22 Catlett also claimed he "did [not] know what being black meant until [he] met blacks direct from the South."23 Michael Lydon links Catlett's feelings to those same emotions expressed by Malcolm X in his autobiography. ${ }^{24}$ Both were lured to an environment where blacks, "'were being their natural

18 Quintard Taylor. The Forging of a Black Community: Seattle's Central District from 1870 through the Civil Rights Era. (Seattle: University of Washington Press, 1994), 161.

19 Taylor, The Forging of a Black Community. 159.

20 MacDonald and Barros, 1.

21 Michael Lydon, Ray Charles: Man and Music (New York: Routledge, 2004) 52. Interestingly, one of the popular clubs on the Jackson Street scene was called the Little Harlem Nightclub, which could signify a connection between the two communities.

22 Ibid, 52-53.

23 Ibid, 53.

24 Ibid. 
selves and not putting on airs," where young "cats" in flashy suits straightened their hair in shiny "conks" and sprinkled their talk with words like "cool" and "hip." 25 The migration from the South and the attitudes and styles that came with it added other important elements to the community in the Central District. It would be the place where many young blacks would forge their identity with a musical instrument in hand.

The Central District was the name given to an section of four square miles that comprised the central area of Seattle. ${ }^{26}$ Charles R. Cross relates that the Central District consisted of a melange of ethnic groups living in Seattle most run-down and ancient homes. ${ }^{27}$ Cross argues that "it was also a tight-knit community where ethnic pride was strong and neighbourhood ties blossomed." 28 In the southern United States, the segregation laws caused a clear division in society, while in the north, segregation was not as readily apparent. ${ }^{29}$ An effect of this less direct form of racism was the development of a close-knit black community in Seattle. That such a community could arise meant that something positive was coming out of a less visible but still derogatory segregation policy. At the time outside of the Central District, landlords restricted blacks from renting homes and municipalities enacted laws that

25 Ibid.

26 Taylor, The Forging of a Black Community, 5.

27 Cross, 13.

28 Ibid.

29 T.V. Reed, The Art of Protest: Culture and Activism from the Civil Rights

Movement to the Streets of Seattle. (Minneapolis: University of Minnesota Press, 2005), 53-54. 
prevented minorities from owning property. ${ }^{30}$ Aside from the attention the Central District music scene received whenever the police raided the clubs, "The Seattle PostIntelligencer stayed 'classical and white."' 31 The ignorance of both the mainstream media and the local record industry facilitated the isolated musical development of the Central District. 32

Blacks were even forced to form their own music union in the form of the American Federation of Musicians (AFM) Local No. 493. ${ }^{33}$ Although Seattle had a significant number of African-American musicians white players did not welcome them into their union." 34 Peter Blecha relates that it caused a cleft between white and black musicians that lasted for decades and did not begin to mend until the two unions amalgamated in 1958. ${ }^{35}$ This dichotomy, however, did not hinder the progress of the black nightclub scene. In fact, places like the black and Tan had become tolerant spaces where different races could interact. ${ }^{36}$ By the time R.C. Robinson came to Seattle alone and by bus in 1948, the Jackson Street scene within the Central District included over thirty clubs, many of which were open all through the night. ${ }^{37}$

\footnotetext{
30 Cross, 12.

31 Lydon, 53.

32 Blecha, Music in Washington, 49.

33 Ibid, 59.

34 Ibid.

35 Ibid.

36 Ibid. The name "Black and Tan" came from the Asian, Black, and white patrons who attended the club during its era of operation, from 1922-1966.

37 MacDonald and Barros, 1.

$$
\begin{gathered}
\text { Past Imperfect } \\
15 \text { [2009] | () | ISSN 1711-053X | elSSN 1718-4487 }
\end{gathered}
$$
}


When R.C. Robinson, better known as Ray Charles, arrived in Seattle he was readily embraced by the Jackson Street scene. The blind piano player was hired to perform in the black and Tan and a dozen other clubs. ${ }^{38}$ Charles, who was under eighteen when he arrived in town, would stay for two years. ${ }^{39}$ It would be in the Rocking Chair, another popular jazz club, where Charles would get his big break. ${ }^{40}$ Jack Lauderdale, president of Down Beat Records in Los Angeles, travelled to Seattle on a tip from musician Jackie McVea, who had played with Charles while touring through Seattle. Lauderdale immediately offered Charles a record deal on the spot after seeing him play. ${ }^{41}$ Due to Seattle being on the geographic periphery of America and far removed from the important centres of the American recording industry, New York and Los Angeles, musicians needed to leave Seattle to become truly successful commercially. ${ }^{42}$ One could only attain a limited amount of celebrity in the Pacific Northwest, for no record label existed in Seattle that had the marketing skills and the industry connections to push local talent into the national spotlight. Thus, Ray Charles left Seattle for a big future in Los Angeles in $1950 .{ }^{43}$ Before he left he met another

\footnotetext{
38 Lydon, 52.

39 Different sources give different accounts of his age. Quincy Jones attests to Charles being sixteen when he arrived, but Michael Lydon and Patrick Macdonald argue that the musician was actually a year older.

40 Ray Charles and David Ritz, Brother Ray: Ray Charles' Own Story (New York: Da Capo Press, 2004), 98, 100. Charles would pen a "happy blues" about the place: If you're feeling lowdown, don't have a soul to care/ just grab your hat and start for the Rocking Chair/. It would also be where Charles was introduced to heroin. Lydon, 57.

41 Lydon, 58.

42 Blecha, Music in Washington, 7.

43 Lydon, 62.
} 
talented young black musician with whom he forged lifelong friendship, Quincy Jones.

Quincy Jones and his family arrived in Seattle in and moved into the Central District in 1947. Jones' father had worked in Bremerton at the Puget Sound Naval Shipyard during the war. There was no longer any work for blacks at the naval shipyard after the Japanese surrender in $1945 .^{44}$ In his autobiography Quincy Jones relates his feelings upon coming to Seattle in the late 1940s:

Seattle was a music mecca at that time. I was ready to explore all that it offered. From 1947 till I left town in 1951, up and down Jackson Street from $1^{\text {st }}$ to $14^{\text {th }}$ Street and all along Madison Street between $21^{\text {st }}$ and $23^{\text {rd }}$, you could find almost any style of music you wanted: bebop, blues, R\&B, even Dixieland. Musicians came from everywhere to hang. Clint Eastwood told me that while bummin' around Portland and Seattle he used to come in regularly to hear our band and check out the babes back then. At the Trianon Ballroom, we'd hang out with Sammy Davis, who was with the Will Mastin Trio. We'd worry him to death all day long. He had all the hip records: early Dizzy, Bird, Monk, all the bebop, Woody Herman's "Lemon Drop," Early Autumn." It had a tremendous influence: he was the first guy we knew who has earphones and a record player

44 Quincy Jones, The Autobiography of Quincy Jones (New York: Broadway Books: 2002), 21, 40.

Past Imperfect 15 [2009] | (C) | ISSN 1711-053X | eISSN 1718-4487 
that held four to six records. We used to play hooky and go see him at the Palomar Theatre. Count Basie, Jimmie Lunceford, Cab Calloway, Duke Ellington, Louis Jordan, T-Bone, Walker, Bull Moose Jackson, Joe “Honeydripper" Liiggins - they roared through town almost every week to play at the Trianon Ballroom, the Civic Center, the Eagle Auditorium, and the Washington Social and Educational Club. ${ }^{45}$

Music played a central role in creating young Jones' sense of identity. His family had troubles because his mother was mentally ill and Quincy did not get along with his stepmother, with whom he lived in a house with his father and brothers. ${ }^{46}$ Jones shared an attic bedroom with his brother Lloyd who agonized at being separated from his sick mother and often fell asleep crying. ${ }^{47}$ Jones could not control his family troubles or stop the angry whites who still referred to him using derogatory expletives. ${ }^{48}$ What he did have power over was his music, and through writing and playing he was able keep these tensions from consuming him . ${ }^{49}$ Jones argues that "jazz gave black men

45 Ibid, 41-42.

$46 \mathrm{Ibid}, 48$.

47 One afternoon Jones and his brother Lloyd were approached on the street by a woman screaming at them. They realized it was their mother, whom they had not seen in four years. She had tracked them down in the Central District.

Neither boy had seen their mother in four years. Jones relates that "my brother and I did the only thing we could do. Instinctively we jumped to our feet, turned on our heels, and ran [away]," 54.

48 Ibid., 48.

49 Ibid., 49. 
and women dignity." ${ }^{50} \mathrm{Jazz}$ music emerged from a tradition based on early slave music and developed a unique niche in American culture. It was a form of expression for blacks that became part of the American consciousness. ${ }^{51}$ In places like St. Louis in the early twentieth century, the popularity of hot-dance music and riverboat jazz was connected to the community's sense of pride and had considerable influence on Miles Davis.

It gave the musicians professional status and increased their esteem socially. ${ }^{52}$ In Seattle, Jones listened to records made by black musicians and he watched blacks perform in local clubs. He felt that he was a part of their world and identified with them. ${ }^{53}$ The environment in the Central District was a positive influence on Jones, enabling him to flourish as a musician. At James A. Garfield High School, the music teacher, Peter Cook, allowed Jones to have control of the band room. ${ }^{54}$ The combination of freedom of expression and creativity was in the foundation that Jones later built upon working in the music industry. Furthermore, in Ray Charles he found a musical kindred spirit and a person to admire because Charles was both successful and his own man. Revealingly, the music community was open and accommodating to a fourteen year old thirsty for acceptance and knowledge. Jones was frequently permitted to awaken musicians that played in

50 Ibid.

51 William "Billy" Taylor, "Jazz: America's Classical Music," The Black Perspective in Music. Vol. 14, No. 1. (Winter, 1986), 21-25.

52 Gerald Early, ed. Miles Davis and American Culture. (St Louis: Missouri

Historical Press, 2001), 30.

53 Jones, 41.

54 Ibid., 45. 
clubs until 4:00 in the morning only two hours later, as he had a trumpet lesson before he went to school.. Quincy Jones's success in the music industry stemmed from his experiences as part of the Central District community. Now this paper will turn to a discussion of another popular musician who had Seattle as his musical foundation, Jimmy Hendrix.

\section{James Marshall Hendrix}

Jimmy Hendrix was born on 27 November 1942 into a broken family. ${ }^{55}$ His mother Lucille and father $\mathrm{Al}$ fought incessantly and Hendrix often spent time with relatives and family friends, floating from home to home around the Central District looking for food and shelter. ${ }^{56}$ Hendrix had four siblings, but three were either made wards of the state or put up for adoption. His brother Leon was his only sibling not given away. They lived in deplorable poverty as Al Hendrix could not hold down a job and spent much of his downtime in various pubs. ${ }^{57}$ Hendrix's parents divorced in 1951 and Lucille died of a ruptured spleen in the spring of

55 Charles Shaar Murray, Crosstown Traffic: Jimi Hendrix and Post-War Pop (London: Faber and Faber Ltd., 1989), 45. His mother Lucille named him John, but when his father returned from Army service in 1945, Al travelled to Berkeley to find his son who had been sent there to live with relatives. Al would rename him his son James after bringing him back to Seattle. Although 'broken family is a highly charged term, it best describes the situation of the Hendrix family when contextualized in the idealized representation of family life at the time in America.

56 Cross, 37. Jimi would also spend a short time with his grandmother in

Vancouver.

57 Ibid., 36. 
1958.58 After Lucille's death, Al Hendrix did not allow his children to attend her funeral. The state of Hendrix's family during his adolescence clarifies how his early life was marked by tragedy and sadness, and that the Central District community took over much of the responsibility for raising him. ${ }^{59}$

The idea of music gave Hendrix hope for a better future although he did not have a real guitar for much of his childhood. Playing music had already become connected to his self-image and Hendrix would often tell his peers that he would become a famous musician when he grew older. This desire came about from growing up in the Central District where musical ability could be equated with status. His first makeshift "instrument" was a broom which he played hard enough to ruin the straw. ${ }^{60}$ Eventually Hendrix managed to get his hands on a beat-up acoustic, which unfortunately lacked actual strings. When he did finally found strings the guitar would never stay in tune because of its warped neck. Eventually his father bought him an electric guitar in 1959 and playing the guitar immediately consumed his life. ${ }^{61}$

A discussion of both Jones and Hendrix's childhood is necessary in order to understand the role of music in their processes of identity formation. Simon Frith asserts

58 Ibid., 58. Lucille had gone to the hospital where staff had failed to recognize the seriousness of her injury. A shroud of mystery hangs over the death, as some close to her believed she may have been beaten by an angry lover.

59 Murray, 46.

60 Cross, 52.

61 Ibid., 65. 
that identity is mobile and is a process rather than a thing. ${ }^{62}$ Stuart Hall argues that this mobile process is not about “'who we are' or 'where we came from' [as] much as what we might become," and "how we have been represented and how that bears on how we might represent ourselves." 63 If a contemporary observer was to place a label on "who Hendrix and Jones were" during their formative years, one might be inclined to focus more on the issues surrounding their domestic situation rather than on their musical prowess. This was not how the two youths, however, perceived themselves. Jones woke up early everyday for trumpet lessons. Hendrix played a broom and attempted to associate himself with music even before he knew how to play a single chord. Both Hendrix and Jones identified more with their own musical potentials rather than the oppressive poverty, broken homes and racism that they experienced in Seattle.

As Jimi Hendrix roamed around the Central District, perfecting his craft on the guitar, Cross asserts that there was no jealously or competitiveness from the other players. Instead it was a matter of pride among black musicians to show others what they knew. ${ }^{64}$ The musicians did not see Hendrix as a potential competitor. For them, music was not simply a part-time escapist dalliance. Music served as the twine that bound the black community of Seattle's Central

62 Simon Frith, "Music and Identity." In Questions of Cultural Identity, edited by Stuart Hall and Paul Du Gay. (London: Sage Publications, 1996), 109.

63 Stuart Hall, "Introduction: Who Needs Identity?" in Stuart Hall and Paul Du Gay (eds)., Questions of Cultural Identity (London: Sage Publications, 1996), 4. ${ }^{64}$ Cross, 63. 
District, and from them Hendrix learned all he could. ${ }^{65}$ Hendrix learned a considerable amount from two musicians in the Lewis family, Dave Sr. and Dave Jr. The former had also shown Ray Charles and Quincy Jones some innovative techniques in years past. 66 Hendrix, then, became part of the tradition the Lewis family had in passing along knowledge to subsequent generations of players within the Central District community.

Cross relates that after Hendrix played "with virtually everyone who owned an instrument in the neighbourhood," he stared playing gigs with local bands. ${ }^{67}$ Hendrix had been a very withdrawn and shy child, but when he was on stage, his awkwardness disappeared completely. ${ }^{68}$ The first important band of which Hendrix was a member was the Velvetones, a group that performed a mixture of $R \& B$, the blues, and jazz. ${ }^{69}$ Hendrix would later play in a band called the Rocking Kings that was primarily focused on rhythm and blues. Most shows were held at venues in and around Seattle. ${ }^{70}$ In late 1960 the Rocking Kings played a show at the Spanish Castle, a popular venue for which DJ Pat O'Day handled most of the bookings. ${ }^{71}$ By the time the Rocking Kings played the venue, jazz and

65 Murray, 47.

66 Cross, 63.

67 Ibid., 66.

68 Murray, 45, 47.

${ }^{69}$ Cross, 66.

70 Ibid., 77., However, on at least one occasion the group headed to a gig in

Vancouver. They never quite made it across the border however because their car broke down on the way.

71 Ibid, 76. Hendrix would later write the song "Spanish Castle Magic" in tribute to the venue. DJ Pat O'Day is credited with, among many other things, being the first American DJ to play the Beatles on air. 
rhythm and blues were accepted and embraced by white musicians. ${ }^{72}$ Larry Coryell, who played in a popular Spanish Castle band, the Checkers, relates that "the Northwest scene was very influenced by African American culture," as shown by the white players adopting the style of the black musicians. ${ }^{73}$

Hendrix was a product of this vibrant black cultural scene. Unfortunately, in the spring of 1961, he would be forced out of Seattle. Caught twice by the police riding in stolen cars, Hendrix was given the choice to either serve in the army or to serve time in prison. On 29 May 1961, Hendrix left for Fort Ord, California, where he enlisted in the $101^{\text {st }}$ Airborne Division. By this time he had been playing with a band called the Tomcats and his farewell show on 28 May drew several hundred people. ${ }^{74}$ An old girlfriend, Carmen Goudy remarked that Hendrix's playing by this time had become much more skilled ${ }^{75}$ Hendrix's musical skills had developed quickly and were a far cry from his early days playing with a broom. The morning after the farewell show Hendrix was gone and he would not return until 1968.

As an African American from the Northwest it was not unusual for Hendrix to join the Army. Cross argues that it was the "most common post-high school choice for African American males" in the Central District around

\footnotetext{
72 Ibid.

73 Ibid.

74 Ibid., 83.

75 Ibid. It is unclear whether or not Goudy has the expertise to label Hendrix's abilities, but the fact that several hundred people turned out for his farewell show strengthens the merit of her assertion.
} 
1960. ${ }^{76}$ Many of Hendrix's friends, faced with limited options, enlisted in the military. In 1965, 23.5 percent of American soldiers killed in action in Vietnam were black, however at that time African-Americans only accounted for 12 percent of the total United States' population. ${ }^{77}$ While white audiences at the Spanish Castle, for instance, were starting to embrace black musical culture, AfricanAmericans still faced much of the same bigotry and prejudices as they had in previous decades. blacks were not allowed to try on clothes in downtown department stores although they were permitted to shop in them. ${ }^{78}$ Working as a clerk in those department stores was also off limits to blacks as were other similar service positions. Despite the restrictions, working in the service industry was one of the few options for African American males. It becomes clear then why many ended up joining the armed forces, even if they were not facing a prison sentence as Hendrix was.

\section{Continued racism in Seattle's central district}

To make matters worse, the black population of the Central District suffered aggressive treatment from the police department. In the late 1950 s a municipal panel was launched into claims of police brutality. ${ }^{79}$ The panel concluded that it was a common belief amongst Seattle's police that any "Negro driving a Cadillac [was] either a

76 Ibid., 79.

77 Douglas T. Miller, On Our Own: Americans in the Sixties (Lexington: D.C. Heath and Company, 1996), 162.

${ }^{78}$ Cross, 78.

${ }^{79}$ Taylor, The Forging of A Black Community, 178. 
pimp or a dope-peddler." 80 In both instances where Hendrix was arrested for riding in a stolen vehicle he had claimed that he had not stolen the car. If he had not joined the army he would have faced a five-year prison term for each offense. ${ }^{81}$

Two other problems were leading to tensions between whites and blacks. One had to do with housing. The influx of black labourers during and following World War Two far outstripped the availability of housing. By 1960, African Americans made up less than five percent of the population of Seattle, however, 80 per cent of the city's 26,901 black residents lived in four of the city's 110 census tracts. ${ }^{82}$ This meant they were mainly in the area comprising the Central District, which had a 37 per cent higher population density than the rest of the city. Besides, houses in this area were rapidly falling apart, and blacks wanted to move to other parts of the city where there was more appropriate housing and better amenities. When they attempted to do so, however, they were met with fierce resistance. In the mid-1950s when blacks began residential expansion into the Madrona-Denny Blaine neighbourhood on the outskirts of the Central District the neighbourhood association president Leslie $H$. Dills mounted a campaign to stop "black infiltration" into the area by instilling fear of an increase in crime and a decrease in property value. ${ }^{83}$

80 Ibid.

81 Cross, 81.

82 Taylor, "Black Protest in Seattle," 3.

83 Taylor, The Forging of A Black Community, 180. Dills went as far to intimidate black residents in the effort to remove them from the neighbourhood, and that lost him the support of the white community. blacks and Asians were gradually 
Furthermore, a 1957 census by the Seattle School Board showed that 81 percent of blacks were concentrated in nine of the city's 112 schools. ${ }^{84}$ Both of these problems attested to the existence of de facto segregation in Seattle.

Taylor argues that once the black community became aware of the above issues, the leadership "eagerly challenged" them, "naively believing that a wellorchestrated campaign of civil disobedience to illustrate the plight of the city's blacks would "educate" the white community on racism and promote a new sense of racial equality, tolerance, and opportunity. ${ }^{85}$ The Central Area Civil Rights Committee (CACRC) was created to "provide one voice on civil rights issues." ${ }^{86}$ Selective-buying campaigns were organized to raise the issue of employment bias and an open housing campaign was started to raise the issue of minorities seeking housing outside the Central District. ${ }^{87}$ These tactics were carried out under the assumption that it was ignorance of the racial problem that kept the white community from taking action. What blacks would instead discover was that Seattle's tolerant image was tainted by strong currents of racism. ${ }^{88}$

An open housing ordinance was put on the ballot in the 10 March 1964 civic election. If passed the ordinance would have punished discrimination of any kind in the

permitted to move into theneighbourhood, a practice that was not followed elsewhere in the city.

84 Taylor, "Black Protest in Seattle," 3.

85 Ibid.

86 Ibid.

87 Ibid., 5.

88 Ibid., 2. 
provision of town housing. ${ }^{89}$ Those most opposed to the housing ordinance expressed their anger by burning crosses and throwing Molotov cocktails onto the porches of black homes. ${ }^{90}$ Two black families had shotguns fired into their homes in Kent, a suburb of Seattle. ${ }^{91}$ The other side was baffled by this reaction. Whites were not merely ignorant of the black condition as opined by Seattle's civil rights leaders. Rather they were openly hostile to a large scale attempt by the black community to deal with the various social problems with which they were presented. J. Dorm Braman, who was running for mayor and opposed the ordinance, won the election against John Cherberg, who had supported the effort to end segregation in the city. The open housing ordinance ballot was defeated 112,448 votes to $53,453.92$ A progressive ordinance had been overwhelmingly struck down by a reactionary backlash in a part of America that had, at least up until that point, been able to trumpet a tolerant image.

While the black community was realizing the depth of racial prejudice in Seattle, their main form of cultural identity was being co-opted, re-branded and comodified for mass white consumption. The Rocking Kings' audience at the Spanish Castle showed that black forms of music like jazz and R\&B were gaining a larger white audience by the late 1950s. Rock ' $n$ ' Roll was gaining popularity in the Northwest just as it was nationally. This interest coincided

\footnotetext{
${ }^{89}$ Ibid., 6.

90 Ibid.

91 Ibid., 6.

92 Ibid.
} 
with local Seattle record producer, Bob Reisdorff, constructing a unique niche in the Pacific Northwest market. ${ }^{93}$ Blecha argues that Reisdorff, the owner of Dolton records, was able to "bypass various nay-saying, big-time music business insiders and push an impressive string of recordings by area teen bands into the national, and then international, spotlight." 94 This was done through "savvy management, adequate capital, [and] effective distribution channels." 95 Reisdorff had a high aptitude for spotting marketable talent. Once he had indentified a potentially marketable group, he already had the necessary infrastructure to launch them nationally. He used his local radio connections to introduce new sounds to the public and he had a strong relationship with $\mathrm{C} \& \mathrm{C}$, a local and independent record distribution company. ${ }^{96}$ The first group Reisdorff recorded, the Fleetwoods, had an international number one hit with the song "Come Softly to Me" in 1959.97 Dolton Records was not created to discover hidden talent in the Pacific Northwest and provide them with a medium to push their abilities to new heights. Hendrix was playing in Seattle at this time and even with his band's local popularity, Residorff appears to have made no overtures towards him. The company was about making a profit by

\footnotetext{
93 Peter Blecha. “Dolton: The Northwest`s First Rock `n`Roll Record Company. History Link.org Essay. 14 March 2006.

http://www.historylink.org/index.cfm?DisplayPage=output.cfm\&file_id=7636 (accessed 25 November 2008).

94 Blecha, Music in Washington, 8.

95 Blecha, “Dolton: The Northwest`s First Rock `n`Roll Record Company.

96 Ibid.

97 Blecha, Music in Washington, 71.

Past Imperfect 15 [2009] | (C) | ISSN 1711-053X | eISSN 1718-4487
} 
marketing 'a hit sound.' 98 At the beginning of the 1960s, the musicians of choice for such a framework were all young, good-looking, and clean-cut white men. ${ }^{99}$ Not surprisingly this occurred during the time period Rolling Stone magazine referred to as the dark age of music. ${ }^{100}$

This development was problematic for the identity of Seattle's black community. Even with the rich traditions of the Central District music scene, black musicians were not promoted by Dolton Records. Instead, it was mainly white imitators who accrued the benefits stemming from Dolton's largesse and connections. Little Bill and the Bluenotes, credited as being the first white teenage $\mathrm{R} \& \mathrm{~B}$ group in the region, were signed to Dolton Records in 1959.101 Countless black R\&B groups had come before the Bluenotes in Seattle after saxophonist Billy Tones had formed the first at the beginning of the decade. ${ }^{102}$ Dolton opened the floodgates for groups like the Paul Revere and the Raiders, the Wailers, the Ventures, and the Kingsmen. Yet a musician as talented as Jimi Hendrix had to go to London to get the attention he deserved. ${ }^{103}$

\footnotetext{
98 Blecha, “Dolton: The Northwest`s First Rock `n`Roll Record Company.” The same approach to promoting Northwest music would be taken in the 1980s, during the grunge era,by the local record company Sub Pop. There were bands which emerged that were original to the Pacific Northwest, such as the protopunk group the Sonics. By the time they formed in 1962 however, Dolton records was no more, having failed in an attempt to move into the Los Angeles market.

98 Bill Harry, The British Invasion: How the Beatles and other UK Bands Conquered North America. (Surrey: Chrome Dreams Publications, 2004), 16. ${ }^{99}$ As cited in: Doug Owram, Born at the Right Time: A History of the Baby Boom Generation (Toronto: University of Toronto Press, 1999), 187. 101 Blecha, "Dolton: The Northwest`s First Rock `n`Roll Record Company.” 102 MacDonald, 1.

103 Blecha, Music in Washington, 8. This generation of bands, combined with others such as the Sonics, would be a part of what is known as "the Pacific 
This exploitation of cultural identity for profit is part of a larger narrative of American culture in this era. Gayle Murchison argues that, "one important cultural need for African Americans is to own their cultural expressions and develop ones that are part of their identity formation." 104 She goes on to say that music played an integral role in this formation. ${ }^{105}$ When African-American culture became coopted by the mainstream, African-Americans responded by moving in a new direction that reflected the community's needs. ${ }^{106}$ This was illustrated by the black community's shift towards civil rights and black power. Murchison relates that in the late 1950s and the 1960s "the music industry repackaged and promoted black music to a white audience," and this reflected "racial divisions in the US."107 This argument has merit regarding the black community of Seattle's Central District in 1968, when Jimi Hendrix returned after becoming an international star.

\section{From identity to civil rights politics}

Seattle had changed significantly in the seven years Hendrix had been away. Due to events like the 1964

Northwest Sound. Admittately, while Hendrix was not yet the skilled virtuoso he would become, his flamboyant style was with him from the very beginning. ${ }^{104}$ Gayle Murchison, comment on "Bill Haley and James Brown are in separate musical streams." The h-southern-music Discussion Logs, comment posted 21 February 2008. http://h-net.msu.edu/cgi-bin/logbrowse.pl?trx=vx\&list=hsouthernmusic\&month $=0802 \&$ week $=c \&$ msg=zIxS1diQP8 $/$ NW7oMm8QYhw\&u ser $=\& p w=($ accessed 20 November 2008).

105 Ibid.

106 Ibid.

107 Ibid. Possibly, Murchison goes too far in her explanation of the exploitation of black culture. Even the DJ Alan Freed is included in her framework as he could be perceived as a promoter of black culture rather than an exploiter of it. 
municipal election and the defeat of the housing ordinance, black leaders were divorced from their racial naivety and the entire community became more politically aware in their fight for equality. They moved away from an identity centred on music and focused more on black power, which was embodied by the black Panther Party for Self Defence and Justice. ${ }^{108}$ As Aaron Dixon relates, the "Black Panther Party represented a proud, defiant presence in the community." 109 While not everyone agreed with the revolutionary ideology of the black Panthers, Dixon, who was the head of the Seattle chapter, felt that the entire community could share in the great sense of pride that the Panthers instilled. ${ }^{110}$ When the city of Seattle had been bitterly divided in 1964 over the Housing Ordinance, Molotov Cocktails had been used by reactionaries to achieve their aims. Interestingly, Dixon used the same tactic in the effort to establish a party headquarters. When at first, Mr. Brill, the landlord of a vacant office, would not rent to Dixon, Molotov cocktails were used to damage Brill's property. Brill promptly changed his mind and allowed the black Panthers to take over the vacant space. ${ }^{111}$

Dixon saw the black Panthers as the defenders of the community. In May of 1968, when they received word that blacks were being targeted at the predominately white

\footnotetext{
108 Nadya Zimmerman, Counterculture Kaleidoscope: Musical and Cultural Perspectives on Late Sixties San Francisco (Ann Arbor: The University of Michigan Press, 2008) 31.

109 Aaron Dixon, "The Panther Comes to Seattle," in Memoirs of a black Panther. 2004, http://www.itsabouttimebpp.com/home/home.html 115.accessed on 10 February 2009.

110 Ibid.

111 Ibid., 110.
} 
Rainier Beach High School, Dixon and twelve other black Panthers made their to the school, armed with rifles, in order to "discuss" the issue with the principle. The men walked straight past a group of police officers and did not leave until the principle had agreed to protect the black students from mistreatment. ${ }^{112}$ Even if blacks in Seattle did not completely embrace the militant nature of the black Panthers, the group was standing up against perceived threats to the community whereas school administrators and police officers were not. Though few actually stood up and fought beside the black Panthers it can be argued their efforts served to heighten the overall political awareness of the Seattle black community. ${ }^{113}$

In February of the same year, when Hendrix stood before an assembly of students at another Seattle school, James A. Garfield High, many had no idea who he even was. Hendrix was expelled from Garfield High for poor attendance and grades but in interviews he propagated a myth that many, including his early biographer Chris Welch, believed. Hendrix told journalists that he had been kicked out of school for holding a white girl's hand rather than for poor academic performance. ${ }^{114}$ Considering the political climate of the time such a story would have been much more sensational than the tale of a dropout. Welch

112 Ibid, 118. Mayor Braman responded to the actions of the black Panthers at Rainier Beach by saying that Seattle police would take action against "anyone trying to take the law into their own hands." Author unknown. "Braman Warns Panthers" Seattle Post-Intelligencer. 13 September 1968.

http://depts.washington.edu/civilr/display.cgi?image=bpp/news/PI_Sept1468-p7.jpg (accessed 21 February 2009).

113 Zimmerman, 33.

114 Chris Welch, Hendrix: A Biography (New York: Flash Books, 1973), 12. 
was not the only biographer to believe Hendrix. It is also related as credible in Curtis Knight's Hendrix biography, Jimi. ${ }^{115}$ When Hendrix stood in front of the students they saw him as a "strange, hippie musician," rather than as a man that had overcome many hardships to become one of the most successful African-Americans of the decade. ${ }^{116}$ Gone were the days when blacks knew the name of every musician that came through town. Instead of admiring Hendrix, they heckled him. ${ }^{117}$ The black power movement became the basis for the students' sense of belonging, weaving together the individual process of identity formation with the collective assertions of the movement. ${ }^{118}$ A new process of identity had developed for the black youth in Seattle, made apparent by their lack of a sense of connection with Hendrix. Aaron Dixon asserted this connection in an interview in the Seattle Times, saying that "the black revolutionary struggle lies on the backs of the young."119

115 Curtis Knight, Jimi: An Intimate Biography of Jimi Hendrix (New York: Praeger Publishers, 1974), 16. It may also reveal a weakness of contemporary biographies that rely on the subject's word while lacking supporting evidence of their claims.

116 Ibid.

117 Ibid.

118 Enrique Larana, Hank Johnston, and Joseph R. Gusfield, eds. New Social Movements: From Ideology to Identity (Philadelphia: Temple University Press, 1994), 8.

119 Author unknown. "125 Attend Last Rites for Dead black Panther" Seattle Times, 13 October 1968.

http://depts.washington.edu/civilr/display.cgi?image=bpp/news/ST_oct1368-p89.jpg (accessed 21 February 2009). Dixon's comments were in response to a young member of the black Panthers, Welton Butch Armstead, being shot to death by Seattle police after being warned to stop pointing a rifle at an officer. Armstead was 17. 
The shift from a cultural to a political identity for the black community was not a cut-and-dry transition. Music was a vital element in the civil rights movement. It was a way for members of the movement to connect across societal lines and it helped organise people in the struggle for change. It was both a common dominator and a rallying cry. ${ }^{120}$ Their goals may have been political but cultural aspects were woven into the effort. "Freedom songs" were created, and the lyrics of artists like Ray Charles were adapted to serve the movement. For example, his song "Moving On" was the story of a man heading on down the road after a love affair turned sour. Instead of the man moving on, the movement's rendering of the tune saw Jim Crow hitting the dusty trail. ${ }^{121}$ This invoked the idea that it was time for America to be rid of the Jim Crow laws, thus immersing a political statement within a cultural form. Before, simply playing music had been enough, but with the music co-option it was no longer enough. On the individual level, the use of a cultural form of protest such as the freedom song could be what led to a "personal political transformation," where a sense if empowerment replaced fear. ${ }^{122}$ Movement members Bruce Hartford and Cordell Reagon relate that the feelings of unity and strength drawn from the sense of community invoked by the freedoms songs helped them overcome their fear of adversity, especially while they were locked in prison cells for protesting. Indeed, Reagon goes as far as to point out that it

120 Reed, 13.

121 Ibid., 21.

122 Ibid., 25.

Past Imperfect 15 [2009] | () | ISSN 1711-053X | eISSN 1718-4487 
was the sound of the community that led them through the darkest times of the political movement. ${ }^{123}$

As cultural elements played a significant role in the civil rights movement, they were also important to the black Power Movement. As Ray Charles' song "Moving On" had been modified to denounce Jim Crow, "Hit the Road, Jack" was changed to "Get Your Rights, Jack." ${ }^{124}$ Aaron Dixon contends that next to Seattle's black Panthers headquarters was a record store where they listened to the latest Motown records. Dixon wanted their headquarters in a place they were already attached to. ${ }^{125}$ Elaine Brown, who was at one time the leader of the Black Panthers claimed that soul music was the "soundtrack" to their movement. ${ }^{126}$ Furthermore, many of the tactics that the black Panthers used successfully were theatrics from their speeches to their confrontation with the authorities. Zimmerman contends that many contemporaries saw the black Panther leaders Bobby Seale and Huey Newton as portraying themselves consciously as icons that symbolized rebellion. ${ }^{127}$ T.V. Reed argues that if one does not grasp the connection between the stylized mixture of "politics" and the "poetics" within the Black Panther Party, then one "fails to understand them at all."128

123 Ibid., 26.

124 Ibid., 36.

125 Dixon, 109.

126 Reed, 36.

127 Zimmerman, 33.

$128 \mathrm{Ibid}, 42$. On the other hand, an identity that is perceived as culturally-based could itself contain political elements. An obvious example would be the blacks living in Los Angeles in the early 1990s. To the soundtrack of "gangsta rap", blacks protested police brutality, especially after the Rodney King beating. On a more subtle level, that most outside the black community would have missed, 
Even Jimi Hendrix, despite the reaction of the Garfield High students had a connection to the black Panthers. Much like members of the Anti-Vietnam War Movement tried to draw Bob Dylan into the political field, various parties within the black Power Movement attempted to forge a connection with Hendrix. That figures such as Michael X wanted to meet with Hendrix because of his prominence demonstrates the intersection of the cultural and the political. ${ }^{129}$ It also shows the importance those with political aims placed upon cultural symbols. When Hendrix one day purchased a Black Panther newspaper on a Harlem street corner the vendor started telling everyone walking past about the purchase, in an abrasive and forceful manner. The black Panthers were in a rivalry with other black groups in Harlem, and the vendor attempted to seize onto the potential legitimacy an association with Hendrix provided. Although Hendrix was constantly asked about the black Panthers by the media, he usually avoided the questions as he did not want to become a spokesperson for the party. ${ }^{130}$ Hendrix, did, however, support them in his own way. When playing a show in

African Americans were protesting with the clothes that they wore. In a discussion with black youths in Los Angeles, Robin Kelley discovered that the L.A. Kings' baseball caps were not symbols of their love for hockey, but rather signified "very powerfully that all young African Americans are potential 'L.A. [Rodney] Kings."' This shows how blurred the lines between the political and the cultural can become. Robin D.G. Kelley, Race Rebels: Culture, Politics, and the Black Working Class. (New York: The Free Press, 1994)., 206. The insert is directed quoted from Kelley.

129 Michael X, or Michael De Freitas, was a radical black activist that would later be executed for murder in 1975 .

130 Cross, 273. 
Berkeley in 1970, Hendrix dedicated the song "Voodoo Child" to the black Panthers. ${ }^{131}$

As blacks in Seattle became more political, awareness in the white community of underlying racism became more common. The employment bias was finally being addressed and even Mayor Braman began supporting affirmative action initiatives. In 1968, the Seattle municipal council passed an open housing measure "unanimously."132 Taylor argues that "the ease with which the City Council enacted the open housing ordinance reflected profound changes Seattle and the nation had undergone in race relations [since 1964]."133 By the 1970s, the Central District would see a mass departure of blacks leaving for other parts of the city. 1980 marked the first time the majority if Seattle's black residents lived outside of the Central District. ${ }^{134}$

\section{Conclusion}

A new process of identity would form for blacks in Seattle during the 1960s. In contrast to the cultural identity that had grown out of the music scene in the Central District, the community shifted towards an identity more political in nature. Certainly, however, elements of the cultural could still be found in the political. This was particularly true for

131 Ibid, 296. Lyrics from the song such as the lines "Well I stand up next to a mountain/ and I chop it down with the edge of my hand/" could have been why Hendrix chose that as the song to dedicate to the black Panthers. Such a dedication would instantly place a political message inside the song. 132 Taylor, "Black Protest in Seattle." 7.

133 Ibid.

134 Ibid., 8. 
music. This new identity arose concurrently with an increase in racial tensions between blacks and whites at the same time as whites were co-opting black music. The two sides eventually moved towards accommodation late in the decade but by that time civil rights held center stage for Seattle minority groups. Peter Blecha writes that Seattle was the ideal example of a microcosm for the cultural reality of the 1960 s. $^{135}$ At the start of the decade blacks acquired a definitive political consciousness and as the 1960s unfolded this would have an impact on equality, the Vietnam War, and how blacks perceived themselves. As Roger Sale concedes, "the deepest of [Seattle's] racial sins [was] ignorance."136 If ignorance had not overrun Seattle in and around 1960, perhaps blacks would not have had to fight simply to move out of the Central District and perhaps Hendrix would have received a hero's welcome when he returned home in 1968. Instead, the cultural landscape of Seattle in 1969 no longer resembled that of the city in 1959, and the same could be said for America as a whole.

135 Blecha, Music in Washington, 59.

136 Roger Sale. Seattle: Past to Present (Seattle: University of Washington Press, 1976), 246.

Past Imperfect 


\section{Bibliography}

Secondary sources

Blecha, Peter. Music in Washington: Seattle and Beyond. USA: Arcadia Publishing, 2007.

Cross, Charles R. Room Full of Mirrors: A Biography of Jimi Hendrix. New York: Hyperion Books, 2005.

Charles, Ray and David Ritz. Brother Ray: Ray Charles' Own Story. New York: Da Capo Press, 2004.

Early, Gerald ed. Miles Davis and American Culture. St Louis: Missouri Historical Press, 2001.

Frith, Simon. "Music and Identity." Stuart Hall and Paul du Gay (eds). Questions of Cultural Identity. London: Sage Publications, 1996.

Hall, Stuart, "Introduction: Who Needs Identity,?" Stuart Hall and Paul du Gay (eds), Questions of Cultural Identity. London: Sage Publications, 1996.

Harry, Bill. The British Invasion: How the Beatles and other UK Bands Conquered North America. Surrey: Chrome Dreams Publications, 2004.

Jones, Quincy. The Autobiography of Quincy Jones. New York: Broadway Books: 2002. 
Kelley, Robin D.G. Race Rebels: Culture, Politics, and the black Working Class. New York: The Free Press, 1994.

Knight, Curtis. Jimi: An Intimidate Biography of Jimi Hendrix. New York: Praeger Publishers, 1974.

Larana, Enrique, Hank Johnston, and Joseph R. Gusfield, eds.

New Social Movements: From Ideology to Identity. (Philadelphia: Temple University Press, 1994.

Lydon, Michael. Ray Charles: Man and Music. New York: Routledge, 2004.

MacDonald, Patrick and Paul De Barros, "Seattle's Fun and Noise: From W.C. Handy to Jimi Hendrix to Robert Cray, the Emerald City has had a Rich History of black Music, The Seattle Times, Sunday 1 February 1998.

Miller, Douglas T. On Our Own: Americans in the Sixties. Lexington: D.C. Heath and Company, 1996.

Murray, Charles Shaar. Crosstown Traffic: Jimi Hendrix and Post-War Pop. London: Faber and Faber Ltd., 1989.

Neely, Kim. Five Against One: The Pearl Jam Story. New York: Penguin Books, 1998.

Owram, Doug. Born at the Right Time: A History of the Baby Boom Generation. Toronto: University of Toronto Press, 1999. 
Reed, T.V. The Art of Protest: Culture and Activism from the civil rights movement to the Streets of Seattle. Minneapolis: University of Minnesota Press, 2005

Sale, Roger. Seattle: Past to Present. (Seattle: University of Washington Press, 1976)

Taylor, William "Billy." "Jazz: America's Classical Music." The Black Perspective in Music. Vol. 14, No. 1. (Winter, 1986). 21-25.

Taylor, Quintard. "Blacks and Asians in a White City: Japanese Americans and African Americans in Seattle, 1890-1940. The Western History Quarterly, Vol. 22, No. 4. November 1991. 401- 429.

Taylor, Quintard. "The civil rights movement in the American West: black Protest in Seattle, 1960-1970." The Journal of Negro History, Vol. 80. No. 1. (Winter 1995), 1-14.

Taylor, Quintard. The Forging of a Black Community: Seattle's Central District from 1870 Through the Civil Rights Era. Seattle: University of Washington Press, 1994.

Welch, Chris. Hendrix: A Biography. New York: Flash Books, 1973.

Zimmerman, Nadya. Counterculture Kaleidoscope: Musical and Cultural Perspectives on Late Sixties San Francisco. Ann Arbor: The University of Michigan Press, 2008. 
WebsitesAnonymous, "125 Attend Last Rites for Dead black Panther," Seattle Times, 13 October 1968. http://depts.washington.edu/civilr/display.cgi?image=bpp /news/ST_oct13-68-p89.jpg, accessed 21 February 2009).

Anonymous, "Braman Warns Panthers" Seattle PostIntelligencer. 13 September 1968.

http://depts.washington.edu/civilr/display.cgi?image=bpp /news/PI_Sept14-68-p7.jpg, accessed 21 February 2009).

Blecha, Peter. “Dolton: The Northwest`s First Rock `n`Roll Record Company. History Link.org Essay, 14 March 2006.http://www.historylink.org/index.cfm?DisplayPage= output.cfm\&file_id=7636, accessed 25 November, 2008).

Dixon, Aaron. "The Panther Comes to Seattle." In, Memoirs of a black Panther. 2004.

http://www.itsabouttimebpp.com/home/home.html (accessed on 10 February 2009).

Murchison, Gayle, "Bill Haley and James Brown are in separate musical streams." The h-southern-music Discussion Logs, comment posted 21 February 2008. http://hnet.msu.edu/cgibin/logbrowse.pl?trx=vx\&list=hsouthernmusic\& month $=0802 \&$ week=c\&msg=zlxS1diQP8/NW7om8QYhw\&user\& $\mathrm{pw}=$ (accessed 20 November 2008).

Concert Recording 
Pearl Jam, Live in Seattle. 6 November 2000. Seattle, Washington. 